\title{
Can co-inoculation of Rhizobium tropici and Azospirillum brasilense increase common bean nodulation and grain yield?
}

\section{A coinoculação de Rhizobium tropici e Azospirillum brasilense pode aumentar a nodulação e o rendimento de grãos do feijoeiro?}

\author{
Fábio Steiner ${ }^{1 *}$; Helen Cristina Pereira Ferreira²; Alan Mario Zuffo ${ }^{3}$
}

\begin{abstract}
The use of plant growth-promoting rhizobacteria (PGPR) associated with rhizobia may optimize the biological nitrogen fixation (BNF), decrease chemical fertilizer-N use and increase plant growth and yield of the bean crop. A study was conducted to investigate the effectiveness of co-inoculation of Rhizobium tropici and Azospirillum brasilense, and nitrogen fertilizer topdressing on nodulation, growth, and yield of common bean (Phaseolus vulgaris L.) in a sandy soil from the Brazilian tropical savanna (Cerrado) region, during the two growing seasons ("spring-summer" and "summer-fall"). The experimental design was a split plot in randomized blocks with four replicates. Plots consisted of four inoculation treatment on seeds: control (non-inoculated); inoculation with Rhizobium tropici; inoculation with Azospirillum brasilense; and co-inoculation with $R$. tropici and A. brasilense; and subplots of five $\mathrm{N}$ rates in topdressing $\left(0,30,60,90\right.$ and $\left.120 \mathrm{~kg} \mathrm{ha}^{-1}\right)$. The inoculation with $R$. tropici alone or combined with $A$. brasilense enhanced root nodulation and grain yield of the common beans when the crop was grown during the dry season in the Brazilian savanna region. Therefore, the positive response of inoculation with rhizobia and azospirilla on the grain yield is dependent of the environmental conditions during the growing season, especially the low rainfall rate by stimulating root nodulation. The inoculation with $A$. brasilense alone was not an efficient agronomic practice to be used in common beans cropping under Brazilian conditions, because resulting grain yield equivalent to the non-inoculated plants in the two growing seasons. The increase of $\mathrm{N}$ application rates inhibits the formation and growth of root nodules of the common beans. The optimal $\mathrm{N}$ application rate in topdressing for common beans grown in sandy soils from the Brazilian savanna region may range between 80 and $90 \mathrm{~kg} \mathrm{~N} \mathrm{Na}^{-1}$.
\end{abstract}

Keywords: Phaseolus vulgaris L. Biological nitrogen fixation. Nitrogen fertilization. Rhizobacteria. Topdressing.

\section{Resumo}

O uso de rizobactérias promotoras de crescimento de planta (RPCP) associado a inoculação de rizóbio pode otimizar a fixação biológica de nitrogênio (FBN), diminuindo o uso de fertilizantes nitrogenados e aumentando o crescimento da planta e o rendimento da cultura do feijão. Um estudo foi conduzido para investigar a eficácia da coinoculação de Rhizobium tropici e Azospirillum brasilense e da adubação nitrogenada em cobertura na nodulação, no crescimento e no rendimento de grãos do feijoeiro (Phaseolus vulgaris L.) cultivado em solo arenoso da região do Cerrado brasileiro, durante duas

1 Prof., Universidade Estadual de Mato Grosso do Sul, UEMS, Unidade Universitária de Cassilândia, Cassilândia, MS, Brasil. E-mail: steiner@uems.br

2 Discente, Curso de Graduação em Agronomia, UEMS, Unidade Universitária de Cassilândia, Cassilândia, MS, Brasil. E-mail: hellencpferreira@outlook.com

3 Prof., Universidade Federal de Mato Grosso do Sul, UFMS, Campus Chapadão do Sul, Chapadão do Sul, MS, Brasil. E-mail: alan_zuffo@hotmail.com

* Author for correspondence 
safras de produção ("safra das águas" e "safra da seca"). O delineamento experimental foi o de blocos casualizados em esquema de parcelas subdivididas, com quatro repetições. As parcelas constituíram de quatro tratamento de inoculação das sementes: controle (não inoculado); inoculação com Rhizobium tropici; inoculação com Azospirillum brasilense; e, coinoculação com R. tropici e A. brasilense; e as subparcelas por cinco doses de $\mathrm{N}$ em cobertura $\left(0,30,60,90\right.$ e $120 \mathrm{~kg} \mathrm{ha}^{-1)}$. A inoculação das sementes com Rhizobium tropici isoladamente ou combinado com Azospirillum brasilense melhorou a nodulação das raízes e o rendimento de grãos do feijoeiro comum quando a cultura foi cultivada durante a "safra da seca". Portanto, a resposta positiva da inoculação das sementes com Rhizobium e Azospirillum no rendimento de grãos depende das condições ambientais durante a safra de produção, especialmente da menor taxa de precipitação pluvial por estimular a nodulação das raízes. A inoculação com A. brasilense isoladamente não foi uma prática agronômica eficiente para ser utilizada no cultivo do feijoeiro nas condições brasileiras, resultando em rendimento de grãos equivalente às plantas do tratamento não inoculado nas duas safras de produção. $\mathrm{O}$ aumento das doses de adubação nitrogenada em cobertura inibe a formação e o crescimento dos nódulos radiculares do feijoeiro. A dose de adubação nitrogenada em cobertura ótima para o cultivo do feijoeiro em solos arenosos da região do Cerrado brasileiro pode variar entre 80 e $90 \mathrm{~kg} \mathrm{ha}^{-1}$ de $\mathrm{N}$.

Palavras-chave: Phaseolus vulgaris L. Fixação biológica de nitrogênio. Adubação nitrogenada. Rizobactérias. Adubação de cobertura.

\section{Introduction}

Brazil is the third largest producer of common beans (Phaseolus vulgaris L.) of the world, surpassed only by Myanmar and India. However, despite the country is among the world's largest bean producers, the average productivity of the crop is relatively low. In the growing seasons of 2017 , the average grain yield of the crop was $1,012 \mathrm{~kg}$ ha $^{-1}$ (CONAB, 2017), considered very low, since the crop has the potential for yields above $3,500 \mathrm{~kg}$ $\mathrm{ha}^{-1}$. This low productivity is mainly because more than $60 \%$ of the national common bean production is produced by smallholder farmers, who use few agricultural inputs and technology.

The use of appropriate management practices, such as nitrogen (N) fertilization and rhizobia inoculation, associated with the use of promising genotypes are strategies to obtain high grain yield and profitability in the common bean crop (SORATTO et al., 2014; PERES et al., 2016; MAIA et al., 2017). Given the high $N$ concentration in the grains and other tissues of the plant; $\mathrm{N}$ is the nutrient most absorbed and removed by the bean plants (SORATTO et al., 2013). However, the efficiency of $\mathrm{N}$ fertilizer use in the production of beans is low, ranging from 30 to $60 \%$ (SANTOS; FAGERIA, 2007). The causes of this low efficiency are related to inadequate rates and times of application, as well as leaching losses, denitrification, immobilization, and soil erosion (MAIA et al., 2012; SORATTO et al., 2014). Thus, to maximize $\mathrm{N}$-use efficiency, grain yield, and profitability of the crop is desirable to improve the synchronism between the $\mathrm{N}$ availability in the soil and the requirement of plants, as well as reduce production costs.

Sustainable agricultural practices that optimize the biological nitrogen fixation (BNF) and yield performance of the common beans are extremely important for Brazilian agriculture, due to the high cost of $\mathrm{N}$ fertilizers and soil $\mathrm{N}$ losses, which may cause significant economic losses to the farmers and negative impacts on the environment (MAIA et al., 2012). In this context, the use of plant growth promoting rhizobacteria (PGPR) in association with inoculation of Rhizobium tropici, a species of rhizobia specific for the nodulation of the common bean roots in Brazilian tropical soils (FERREIRA et al., 2000), may be a viable technique to improve the efficiency of BNF, reduce the chemical fertilizer-N use and increase yield of the beans.

The PGPR are highly beneficial to agriculture worldwide, acting in plant nutrition, protection, and growth stimulation (PERRIG et al., 2007; CASSÁN et al., 2009). Azospirillum is, certainly, the most 
employed PGPR in the world (HUNGRIA et al., 2010, 2015; MARKS et al., 2013; BULEGON et al., 2017), but little is known about its interaction with rhizobia, when both are applied in common bean seeds (PERES et al., 2016).

Recent research results have proven the beneficial effects of the co-inoculation of rhizobia and Azospirillum brasilense on nodulation, $\mathrm{N}$ supply and growth of leguminous plants, especially on soybean (HUNGRIA et al., 2013; MARKS et al., 2013; CHIBEBA et al., 2015, HUNGRIA et al., 2015; BULEGON et al., 2017). However, the effect of co-inoculation on nodulation, plant growth and yield of the beans crop is still incipient and inconclusive. Indeed, Hungria et al. (2013) reported that the co-inoculation of $R$. tropici and A. brasilense resulted in a mean yield increase of $187 \mathrm{~kg} \mathrm{ha}^{-1}$ (about 12\%) in beans, compared to the inoculation of $R$. tropici alone. However, Peres et al. (2016) reported that co-inoculation of $R$. tropici combined with $A$. brasilense did not affect the grain yield of beans in the two growing seasons, compared to the application of $80 \mathrm{~kg} \mathrm{~N} \mathrm{ha}^{-1}$ in topdressing. These and other contradictory results justify the need of conducting more research in order to investigate the effects of co-inoculation with $R$. tropici and $A$. brasilense on cropping of common beans.

This study was conducted to investigate the effectiveness of co-inoculation of Rhizobium tropici and Azospirillum brasilense and nitrogen fertilizer topdressing on nodulation, growth and yield of common bean (Phaseolus vulgaris L.) in a sandy soil from the Brazilian tropical savanna (Cerrado) region, during two growing seasons ("springsummer" and "summer-fall").

\section{Material and Methods}

Study site description

The experiments were conducted in a deep, sandy Arenic Entisol with 84-86\% of sand, in Cassilândia, Mato Grosso do Sul, Brazil (1905'20" S, 51 48'24" $\mathrm{W}$, and altitude of $470 \mathrm{~m}$ ). The experiments were carried out during the spring-summer season (from November 2015 to February 2016) and summer-fall season (from March to June 2016). The regional climate according to the Köppen classification is Aw, characterized as tropical climate with hot summers and a tendency towards high rainfall levels, and dry winters, with a dry season between May and September. The 30-years mean annual temperature is $24.1{ }^{\circ} \mathrm{C}$ with a July minimum of $16.4{ }^{\circ} \mathrm{C}$ and a January maximum of $28.6{ }^{\circ} \mathrm{C}$, and mean annual rainfall of $1,520 \mathrm{~mm}$. Rainfall and temperature data gathered during the experiments are shown in Figure 1. The total rainfall during the spring-summer growth season was $535 \mathrm{~mm}$, while in the summer-fall growth season was $242 \mathrm{~mm}$.

Prior to this experiment, the area had no known history of Rhizobium inoculation and had been occupied by Urochloa sp. pasture without any fertilization for 12 years. Before starting the experiments, the soil was sampled from the $0-0.20 \mathrm{~m}$ layer. The main chemical properties were as follow: $\mathrm{pH}$ in $\mathrm{CaCl}_{2}$ of $5.2,14 \mathrm{~g} \mathrm{~kg}^{-1}$ of organic matter, 2 $\mathrm{mg} \mathrm{dm}{ }^{-3}$ of P (Resin), $22 \mathrm{mmol}_{\mathrm{c}} \mathrm{dm}^{-3}$ of $\mathrm{H}+\mathrm{Al}, 2$ $\mathrm{mmol}_{\mathrm{c}} \mathrm{dm}^{-3}$ of $\mathrm{K}^{+}, 10 \mathrm{mmol}_{\mathrm{c}} \mathrm{dm}^{-3}$ of $\mathrm{Ca}^{2+}, 7 \mathrm{mmol}_{\mathrm{c}}$ $\mathrm{dm}^{-3}$ of $\mathrm{Mg}^{2+}$, and $46 \%$ of soil base saturation. Lime ( $\mathrm{CaO} 25 \%, \mathrm{MgO} 12 \%$, and EEC 92\%) was applied at $1,070 \mathrm{~kg} \mathrm{ha}^{-1}$ to raise soil base saturation to $70 \%$. After liming, the field was plowed and harrowed to a depth of $0.25 \mathrm{~m}$ and divided into plots before sowing. The second trial was carried out in the same area and with the same arrangement of the first trial plots.

\section{Experimental design and treatments}

The experimental design was a split plot in randomized blocks with four replicates. In the main plot, treatments were established by four inoculation treatments: i) control (non-inoculated); ii) inoculation with Rhizobium tropici; iii) inoculation with Azospirillum brasilense; and iv) co-inoculation with $R$. tropici and A. brasilense, and five $\mathrm{N}$ rates in topdressing $\left(0,30,60,90\right.$ and $\left.120 \mathrm{~kg} \mathrm{ha}^{-1}\right)$ were established in subplots. The main plots were $5.0 \times$ $12.5 \mathrm{~m}$, and the sub-plots were $5.0 \times 2.5 \mathrm{~m}$. 
Figure 1. Daily rainfall $(\mathrm{mm})$ and average temperature $\left({ }^{\circ} \mathrm{C}\right)$ during two growing seasons ("spring-summer" and "summer-fall") of common beans in Cassilândia, MS, Brazil.

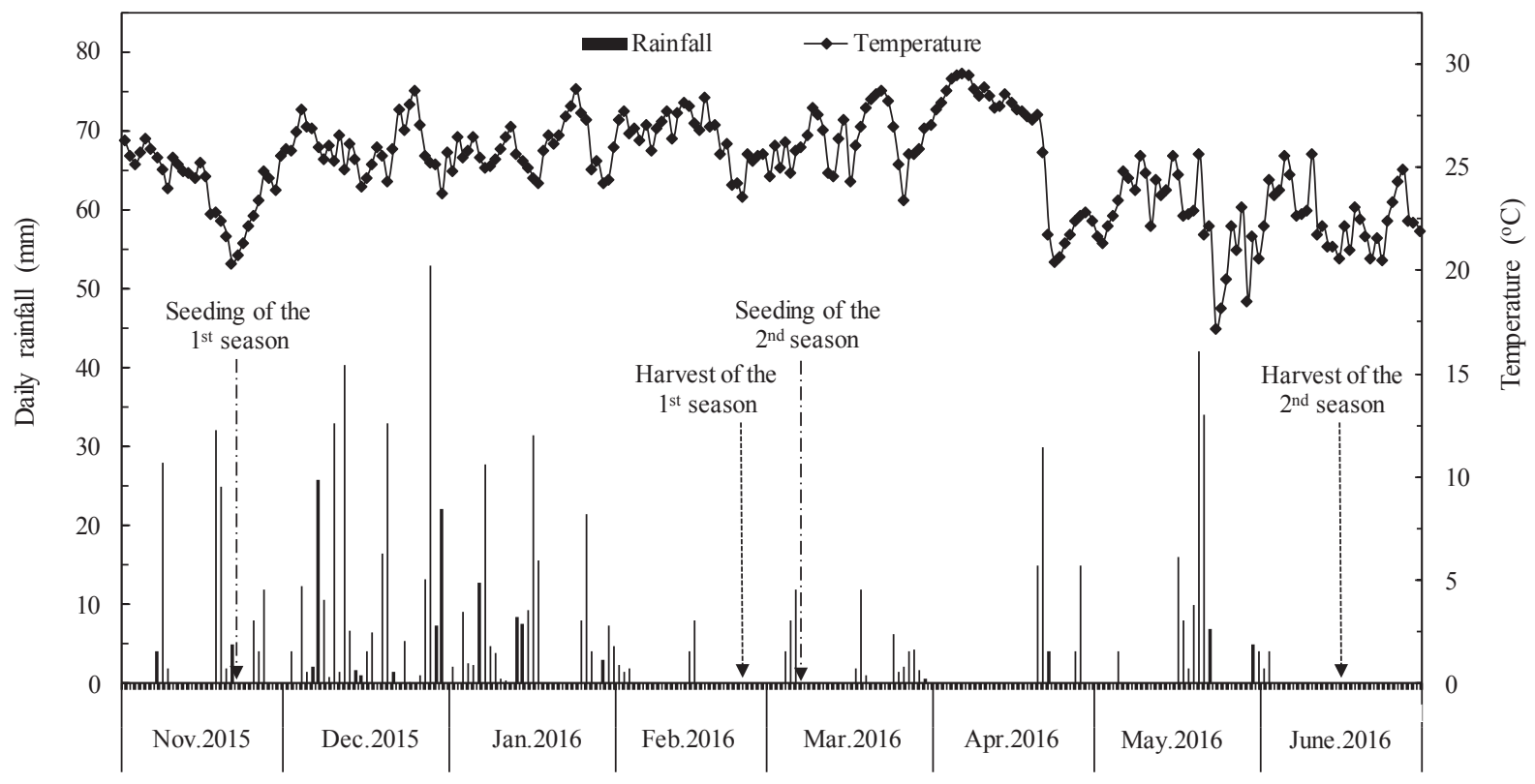

The experimental units consisted of five $5.0-\mathrm{m}$ long rows, with $0.50-\mathrm{m}$ between-row spacing in both crop growing seasons ("spring-summer" and "summer-fall"). The useful area were the three central rows of each subplot, in which two rows were for grain yield and one to collect plants and roots, disregarding $0.50 \mathrm{~m}$ of each edge.

\section{Plant materials, inoculation, and fertilization}

Common bean was sown mechanically, on November 22, 2015 (spring-summer season) and March 07, 2016 (summer-fall season), in rows 0.50 $\mathrm{m}$ apart at a density of 15 seeds $\mathrm{m}^{-1}$. Base fertilization was carried out by applying $600 \mathrm{~kg} \mathrm{ha}^{-1}$ 04-14-08 formulation at sowing. Nitrogen application rates $\left(30,60,90\right.$ and $\left.120 \mathrm{~kg} \mathrm{ha}^{-1}\right)$ were split into two applications at 25 and 40 days after emergence (DAE), as urea $(45 \% \mathrm{~N})$. The bean cultivar used in both experiments was the "Pérola", which has a Carioca type grain, average mass of 100 seeds of 23 to $27 \mathrm{~g}$, growth habit type II/III (prostrate with greater branching) and an average cycle ranging from 85 to 95 days (RAMALHO; ABREU, 2006).
Seed inoculation with Rhizobium tropici was carried out with the commercial liquid inoculant Nitro1000 ${ }^{\circledR}$ Feijão (Nitro1000: Biological Inoculants) containing the SEMIA 4077, SEMIA 4080 and SEMIA 4088 strains (minimum concentration of $3.0 \times 10^{9}$ viable cells per $\mathrm{mL}$ ), at the rate of $200 \mathrm{~mL}$ for $25 \mathrm{~kg}$ of seeds. For the inoculation with Azospirillum brasilense, the commercial liquid inoculant Nitro $1000^{\circledR}$ Gramíneas (Nitro1000: Biological Inoculants) containing the $\mathrm{AbV}_{5}$ and $\mathrm{AbV}_{6}$ strains (minimum concentration of $2.0 \times 10^{8}$ viable cells per $\mathrm{mL}$ ) was used, at a rate of $200 \mathrm{~mL}$ per $25 \mathrm{~kg}$ of seeds. The co-inoculation was performed by mixing the two rhizobacteria at the same proportions used when inoculated alone, that is, $200 \mathrm{~mL}$ of inoculant containing $R$. tropici +200 $\mathrm{mL}$ of inoculant containing $A$. brasilense for $25 \mathrm{~kg}$ of seeds.

Management of weeds, pests, and diseases was carried out according to the needs and technical recommendation of the crop. The harvest was performed manually, on February 24, 2016, at 86 days after plant emergence in the spring-summer 
season. In the summer-fall season, the bean was harvested manually, on June 15, 2016, at 94 days after the plant emergence.

\section{Plant sampling and measurements}

Nodulation and dry matter production of bean plants were assessed at the beginning of pod development $\left(\mathrm{R}_{3}\right.$ stage) at $46 \mathrm{DAE}$ (spring-summer season) and 52 DAE (summer-fall season). Six plants of each subplot were cut at the soil surface, and then roots were carefully dug out and collected into polythene bags, together with detached nodules and transported to the laboratory. The roots were put in a $1.0 \mathrm{~mm}$ mesh sieve and washed under running tap water to remove adhered soil. The nodules were gently removed, washed, and counted. Shoot, roots, and nodules were ovens dried at $60{ }^{\circ} \mathrm{C}$ for $72 \mathrm{~h}$ and then weighed.

Relative chlorophyll index (RCI) was measured at the $\mathrm{R}_{3}$ stage using a portable chlorophyll meter, Apogee model MC-100 (Apogge Instruments Inc., Logan, UT, USA), with ten measurements in the subplots at the third trifoliolate leaf totally expanded as recommended by Maia et al. (2017). In each evaluation, two readings per leaflet were performed for all the diagnostic leaves evaluated, along the leaf blade and avoiding the ribs. After measuring the $\mathrm{RCI}$, the leaves were collected for the determination of $\mathrm{N}$ concentrations. The leaf samples were dried for three days at $55{ }^{\circ} \mathrm{C}$, ground in a Willey mill, and $\mathrm{N}$ was determined by sulfuric acid digestion and vapor distillation by the semi-micro Kjeldahl method (MALAVOLTA et al., 1997).

At harvest, the final plant stand, grain yield, and production components (pod number per plant, grain number per pod and mass of 100 grains) were evaluated. The final stand was obtained by counting the total number of plants of the useful area of each subplot. Grain yield was determined at the end of the crop's cycle, from a central portion of each subplot of $4.0 \times 1.0 \mathrm{~m}\left(4.0 \mathrm{~m}^{2}\right)$. Grains were cleaned and weighed, and grain yield was estimated after correction of grain weights to $13 \%$ moisture. The average pod number per plant and average grain number per pod were determined in a random sample of ten plants in the useful area of subplot, and the mass of 100 grains by the average of three weighing's of one hundred grains taken at random.

\section{Statistical analysis}

The normality of data was previously tested by the Kolmogorov-Smirnov test at the 5\% level and then data were submitted to analysis of variance (ANOVA) and, when significant, the means of inoculation treatments were compared by Tukey test at the 0.05 level of confidence. Regression analysis was used for the $\mathrm{N}$ fertilizer rates and significant equations ( $\mathrm{F}$ test, $P \leq 0.05$ ) with the greatest determination coefficients were adjusted. The analyses were performed using Sisvar ${ }^{\circledR}$ software, version 5.6 for Windows (Statistical Analysis Software, UFLA, Lavras, MG, BRA).

\section{Results and Discussion}

A summary of the analysis of variance for the measurements of nodulation, nitrogen nutrition, dry matter, grain yield and production components of common beans crops is shown in Table 1. Analysis of variance did not show significant effects $(P>$ 0.05 ) for the interaction between inoculation and $\mathrm{N}$ application rates for any of the traits measured (Table 1). Therefore, the results are presented separately for the main effects of inoculation and $\mathrm{N}$ rate application. The absence of significant interaction among the studied factors indicates that the $\mathrm{N}$ fertilizer application in topdressing has a similar response in the bean crop, regardless of the inoculation or non-inoculation with $R$. tropici and $A$. brasilense either alone or in combination. 
Table 1. Summary of the analysis of variance for the measurements of nodulation, nitrogen nutrition, dry matter, grain yield and production components of common beans crops as affected by inoculation of Rhizobium tropici and/or Azospirillum brasilense and nitrogen fertilization in topdressing, during the two growing seasons ("spring-summer" and "summer-fall").

\begin{tabular}{|c|c|c|c|c|c|c|c|c|c|c|c|}
\hline \multirow{2}{*}{$\begin{array}{l}\text { Causes of } \\
\text { variation }\end{array}$} & \multicolumn{11}{|c|}{ Probability $>F$} \\
\hline & NNP & NDM & SDM & RDM & $\mathrm{N}$ & $\mathrm{RCI}$ & FPS & NPP & NGP & $100-\mathrm{G}$ & GY \\
\hline & \multicolumn{11}{|c|}{ Spring-summer season (2015-2016) } \\
\hline Block & 0.274 & 0.317 & 0.163 & 0.461 & 0.372 & 0.498 & 0.134 & 0.167 & 0.132 & 0.395 & 0.413 \\
\hline Inoculation (I) & 0.006 & 0.002 & 0.042 & 0.024 & 0.135 & 0.213 & 0.220 & 0.025 & 0.347 & 0.178 & 0.208 \\
\hline Nitrogen rates $(\mathrm{N})$ & 0.034 & 0.003 & $<0.000$ & 0.172 & $<0.000$ & $<0.000$ & 0.431 & 0.008 & 0.431 & 0.030 & $<0.000$ \\
\hline $\mathrm{I} \times \mathrm{N}$ & 0.263 & 0.118 & 0.186 & 0.353 & 0.116 & 0.387 & 0.726 & 0.236 & 0.249 & 0.486 & 0.396 \\
\hline $\mathrm{CV}_{\text {Plot }}(\%)$ & 12.75 & 15.83 & 14.34 & 11.28 & 8.73 & 6.84 & 7.93 & 9.46 & 8.82 & 9.74 & 13.52 \\
\hline \multirow[t]{2}{*}{$\mathrm{CV}_{\text {Subplot }}(\%)$} & 11.41 & 15.59 & 12.94 & 17.61 & 7.48 & 5.97 & 6.91 & 8.28 & 4.27 & 7.17 & 11.45 \\
\hline & \multicolumn{11}{|c|}{ Summer-fall season (2016) } \\
\hline Block & 0.012 & 0.214 & 0.074 & 0.325 & 0.873 & 0.497 & 0.641 & 0.732 & 0.474 & 0.511 & 0.118 \\
\hline Inoculation (I) & $<0.000$ & $<0.000$ & 0.043 & 0.008 & 0.140 & 0.173 & 0.351 & $<0.000$ & 0.109 & 0.273 & 0.036 \\
\hline Nitrogen rates $(\mathrm{N})$ & $<0.000$ & $<0.000$ & 0.441 & 0.193 & $<0.000$ & $<0.000$ & 0.234 & 0.012 & 0.684 & 0.007 & $<0.000$ \\
\hline $\mathrm{I} \times \mathrm{N}$ & 0.098 & 0.287 & 0.472 & 0.631 & 0.088 & 0.214 & 0.821 & 0.465 & 0.351 & 0.332 & 0.143 \\
\hline $\mathrm{CV}_{\text {Plot }}(\%)$ & 19.63 & 21.46 & 8.92 & 15.87 & 7.54 & 6.13 & 6.91 & 8.28 & 4.27 & 7.17 & 11.45 \\
\hline $\mathrm{CV}_{\text {Subplot }}(\%)$ & 18.01 & 17.72 & 7.37 & 7.01 & 6.24 & 6.59 & 15.21 & 8.13 & 13.69 & 6.45 & 8.78 \\
\hline
\end{tabular}

NNP: nodule number per plant. NDM: nodule dry matter. SDM: shoot dry matter. RDM: root dry matter. N: leaf nitrogen concentration. RCI: relative chlorophyll index. FPS: final plant stand. NPP: number of pods per plant. NGP: number of grains per pod. 100-G: 100-grain weight. GY: grain yield.

\section{Nodulation, plant growth, and nitrogen uptake}

The inoculation with $R$. tropici and $A$. brasilense either alone or in combination significantly affect $(P$ $<0.05)$ the nodulation and dry matter accumulation of shoot and roots of bean plants in both growing seasons (Table 2). In the spring-summer season, the nodule number per plant ranged from 15.3 to 45.4, and was significantly greater when plants were coinoculated with the two rhizobacteria, followed by inoculation of $R$. tropici and A. brasilense both alone, and lower in non-inoculated plants (Table 2). Nodule dry matter was significantly higher with inoculation of $R$. tropici and $A$. brasilense either alone or in combination, and lower in non- inoculated plants (Table 2). In the summer-fall season, the number and dry matter of nodules per plant was significantly greater when plants were inoculated with $R$. tropici alone or combined with $A$. brasilense, and lower with inoculation of $A$. brasilense and in the non-inoculated control (Table 2). It is interesting to note that although the co-inoculation only increased the nodulation in relation to the inoculation with rhizobia alone in the spring-summer season, no incompatibility was verified between the inoculants applied to the seeds, confirming the results reported by Hungria et al. (2015) for the co-inoculation of soybean seeds. 
Table 2. Effect of (co)inoculation of Rhizobium tropici and/or Azospirillum brasilense on nodule number per plant, nodule dry matter, shoot dry matter, root dry matter, leaf nitrogen concentration and relative chlorophyll index of common bean plants (Phaseolus vulgaris L., cv. Pérola) grown in a sandy soil from the Brazilian savanna region, during the two growing seasons ("spring-summer" and "summer-fall").

\begin{tabular}{|c|c|c|c|c|c|c|}
\hline \multirow[t]{2}{*}{ Inoculation treatment } & $\begin{array}{c}\text { Nodules per } \\
\text { plant }\end{array}$ & $\begin{array}{c}\text { Nodule dry } \\
\text { matter }\end{array}$ & $\begin{array}{l}\text { Shoot dry } \\
\text { matter }\end{array}$ & $\begin{array}{c}\text { Root dry } \\
\text { matter }\end{array}$ & $\begin{array}{l}\mathrm{N} \text { concen- } \\
\text { tration }\end{array}$ & $\begin{array}{l}\text { Chlorophyll } \\
\text { index }\end{array}$ \\
\hline & (units) & $\left(\right.$ mg plant $\left.^{-1}\right)$ & $\left(\right.$ g plant $\left.^{-1}\right)$ & $\left(\right.$ g plant $\left.^{-1}\right)$ & $\left(\mathrm{g} \mathrm{kg}^{-1}\right)$ & \\
\hline & \multicolumn{6}{|c|}{ Spring-summer season (2015-2016) } \\
\hline Control & $15.3 \mathrm{c}$ & $30.8 \mathrm{~b}$ & $8.06 \mathrm{~b}$ & $2.92 \mathrm{~b}$ & $37.7 \mathrm{a}$ & $47.5 \mathrm{a}$ \\
\hline Rhizobium tropici & $31.7 \mathrm{~b}$ & $67.2 \mathrm{a}$ & $9.62 \mathrm{ab}$ & $4.30 \mathrm{a}$ & $41.9 \mathrm{a}$ & $51.4 \mathrm{a}$ \\
\hline Azospirillum brasilense & $26.5 \mathrm{~b}$ & $61.7 \mathrm{a}$ & $9.04 \mathrm{ab}$ & $3.92 \mathrm{a}$ & $40.2 \mathrm{a}$ & $48.7 \mathrm{a}$ \\
\hline R. tropici $+A$. brasilense & $45.4 \mathrm{a}$ & $82.4 \mathrm{a}$ & $10.96 \mathrm{a}$ & $4.85 \mathrm{a}$ & $43.1 \mathrm{a}$ & $50.6 \mathrm{a}$ \\
\hline \multirow[t]{2}{*}{$\mathrm{CV}(\%)$} & 12.75 & 15.83 & 14.34 & 11.28 & 8.73 & 6.84 \\
\hline & \multicolumn{6}{|c|}{ Summer-fall season (2016) } \\
\hline Control & $78.0 \mathrm{~b}$ & $180.3 \mathrm{~b}$ & $4.58 \mathrm{~b}$ & $2.26 \mathrm{~b}$ & $35.2 \mathrm{a}$ & $42.8 \mathrm{a}$ \\
\hline Rhizobium tropici & $198.6 \mathrm{a}$ & $571.1 \mathrm{a}$ & $5.62 \mathrm{a}$ & $3.39 \mathrm{a}$ & $38.9 \mathrm{a}$ & $44.2 \mathrm{a}$ \\
\hline Azospirillum brasilense & $93.8 \mathrm{~b}$ & $213.8 \mathrm{~b}$ & $5.51 \mathrm{a}$ & $3.30 \mathrm{a}$ & $36.3 \mathrm{a}$ & $44.9 \mathrm{a}$ \\
\hline R. tropici $+A$. brasilense & $166.5 \mathrm{a}$ & $525.4 \mathrm{a}$ & $5.33 \mathrm{a}$ & $3.65 \mathrm{a}$ & $37.9 \mathrm{a}$ & $46.9 \mathrm{a}$ \\
\hline CV (\%) & 19.63 & 21.46 & 8.92 & 15.87 & 7.54 & 6.13 \\
\hline
\end{tabular}

Values represented by the different letters show significant differences (Tukey test, $\mathrm{p}<0.05$ ). CV: coefficient of variation.

Co-inoculation resulted in a $43 \%$ increase in the nodule number per plant compared to inoculation of rhizobia alone in the spring-summer season. The beneficial effect of the co-inoculation of rhizobia and azospirilla on nodulation has been commonly reported in several crops, such as soybean (CHIBEBA et al., 2015), bean (PERES et al., 2016) and peanut (SILVA et al., 2017). Peres et al. (2016) measured the increase in bean nodulation of $149 \%$, using the co-inoculation with $R$. tropici and A. brasilense compared to the inoculation with $R$. tropici alone. Similarly, Silva et al. (2017) reported that inoculation of Bradyrhizobium japonicum combined with $A$. brasilense resulted in an increase in the peanut nodulation of $56 \%$ compared to inoculation of B. japonicum alone. This increase in root nodulation with co-inoculation may have been due to the synergistic effect of rhizobia and azospirilla bacteria in improving the formation of root nodules in leguminous plants. The beneficial effects of mixed inoculation with symbiotic ( $R$. tropici) and non-symbiotic (A. brasilense) bacteria in leguminous plants are mostly due to the capacity of these rhizobacteria to fix atmospheric nitrogen $\left(\mathrm{N}_{2}\right)$, produce plant-growth hormones, increase nitrate reductase enzyme activity, induce plant resistance to stress and disease and solubilize phosphate from the soil (PERRIG et al., 2007; CASSÁN et al., 2009; CHIBEBA et al., 2015; FUKAMI et al., 2018). These results report the importance of the combined use of rhizobia and azospirilla to improve the efficiency of biological $\mathrm{N}$ fixation and reduce the chemical fertilizer-N use and production costs in the common beans cropping in sandy soils from the Brazilian tropical savanna region.

The lower number of root nodules (Table 2) found in the spring-summer season may be related to the higher rainfall rate observed during this growing season (Figure 1). The survival of soil bacterial community is dependent on several factors such as soil $\mathrm{pH}$, nutrient concentration, salinity, and soil water content. Vurukonda et al. (2016) showed that the soil bacterial population is reduced with 
the increase of the rainfall rate; however, bacterial diversity is independent of precipitation gradient. Furthermore, the increase in the number of nodules in the summer-fall season may be due to the two experiments being performed in the same area. The cultivation of the first bean harvest can be improved the soil Rhizobium population which reflected in increased nodulation in the second trial.

The inoculation with $R$. tropici and A. brasilense either alone or in combination resulted in the higher dry matter accumulation of shoot and roots compared to non-inoculated plants in both growing seasons, but leaf $\mathrm{N}$ concentration and relative chlorophyll index were not significantly affected $(P>0.05)$ by inoculation or non-inoculation of the plants (Table 2). These results indicate that the inoculation of symbiotic and non-symbiotic bacteria in bean crops improved the growth and dry matter accumulation of the plants. The PGPR may promote plant growth through the production of plant hormones, mainly indole-3-acetic acid (IAA) an auxin (VURUKONDA et al., 2016; FUKAMI et al., 2018). Plants inoculated with PGPR producing IAA, such as Azospirillum brasilense, have an increase in the formation of lateral roots and root hairs and/or higher root growth, increasing water and nutrient uptake, which can help plants to overcome environmental stresses and improving the dry matter accumulation of the plants (DIMKPA et al., 2009; CHIBEBA et al., 2015; BULEGON et al., 2017).

The higher growth of the common bean plants promoted by the inoculation of rhizobia and azospirilla resulted in the greater $\mathrm{N}$ dilution in the leaf tissue of plants, which explains the absence of inoculation effect in the $\mathrm{N}$ concentration and relative chlorophyll index (Table 2). Equivalent results were reported by Peres et al. (2016), who evaluated the effect of co-inoculation of common bean plants with $R$. tropici and $A$. brasilense also did not report a significant effect on leaf $\mathrm{N}$ concentration when compared to the application of $80 \mathrm{~kg} \mathrm{~N} \mathrm{ha}^{-1}$ in topdressing.
The nodulation (number and dry matter) decreased progressively with increasing $\mathrm{N}$ fertilizer rate in topdressing in both growth seasons (Figure $2 \mathrm{~A}$ and $2 \mathrm{~B}$ ). The application of $120 \mathrm{~kg} \mathrm{~N} \mathrm{ha}{ }^{-1}$ reduced the nodule number per plant in $18 \%$ and $23 \%$ compared to the not fertilized treatment with $\mathrm{N}$, respectively, for the spring-summer and summerfall seasons (Figure 2A). The decrease of nodule dry matter in the treatments with the application of $120 \mathrm{~kg} \mathrm{~N} \mathrm{ha}^{-1}$ were $20 \%$ and $26 \%$ for the springsummer and summer-fall seasons, in relation to the not fertilized treatment with N, respectively (Figure 2B).

These results indicated that $\mathrm{N}$ application inhibited the formation of root nodules of the common bean plants. Inhibition of the nodulation process in leguminous plants with the application of $\mathrm{N}$ fertilizer has been reported in other studies. Pelegrin et al. (2009) found that the application of 60 and 140 $\mathrm{kg} \mathrm{N} \mathrm{ha}{ }^{-1}$ in topdressing resulted in a decrease in the nodule numbers of $41 \%$ and $79 \%$, respectively, compared to common bean plants inoculated with Rhizobium tropici strain CIAT 899 (SEMIA 4077). In cowpea plants (Vigna unguiculata L. Walp.) inoculated with Bradyrhizobium strains, Santos et al. (2014) showed that the application of $80 \mathrm{~kg}$ $\mathrm{N}$ ha ${ }^{-1}$ significantly reduced the number and dry matter of root nodules. In soybean plants, Saito et al. (2014) also showed that application of $\mathrm{N}$ strongly inhibited the formation and growth rate of nodules. Negative effects of $\mathrm{N}$ fertilizer addition on nodule formation in the leguminous plants are due to its role in inhibiting the metabolism of plant phenolic compounds, especially the synthesis and release of isoflavonoids by the leguminous roots (ECKARDT, 2006; WASSON et al., 2006). The isoflavonoids released by leguminous plant roots have been reported to play multiple roles at different stages of the nodulation process, especially because it acts as chemo-attractants of rhizobia and regulates the nod genes expression (ECKARDT, 2006). Indeed, Wasson et al. (2006) reported that the lower release of flavonoids by plant roots caused by RNA 
interference of chalcone synthase resulted in the inability of leguminous plant roots to initiate the formation of root nodules. Therefore, it is verified that the stimulus to initiate nodule formation is dependent on the $\mathrm{N}$ concentration of the soil, and the increased application rates of this nutrient results in inhibition of nodule formation (lower number of nodules per plant, see Figure 2A) and reduction of nodule growth (smaller size nodules, see Figure
2B). Furthermore, the process of symbiotic $\mathrm{N}$ fixation has a large energy cost for plants. Symbiotic microorganisms that fix atmospheric $\mathrm{N}$ require 16 moles of adenosine triphosphate (ATP) to reduce each mole of $\mathrm{N}$, and these microorganisms obtain this energy from their host plants' rhizospheres (HUBBELL; KIDDER, 2009). Therefore, in soils with greater $\mathrm{N}$ availability the biological fixation process is reduced to minimize the energy costs of the Rhizobium-bean symbiosis.

Figure 2. Effect of nitrogen fertilizer rates in topdressing on nodule number per plant (A), nodule dry matter (B), shoot dry matter (C), and root dry matter (D) of common bean plants (Phaseolus vulgaris L., cv. Pérola) grown in a sandy soil from the Brazilian savanna region, during the two growing seasons ("spring-summer" and "summer-fall").
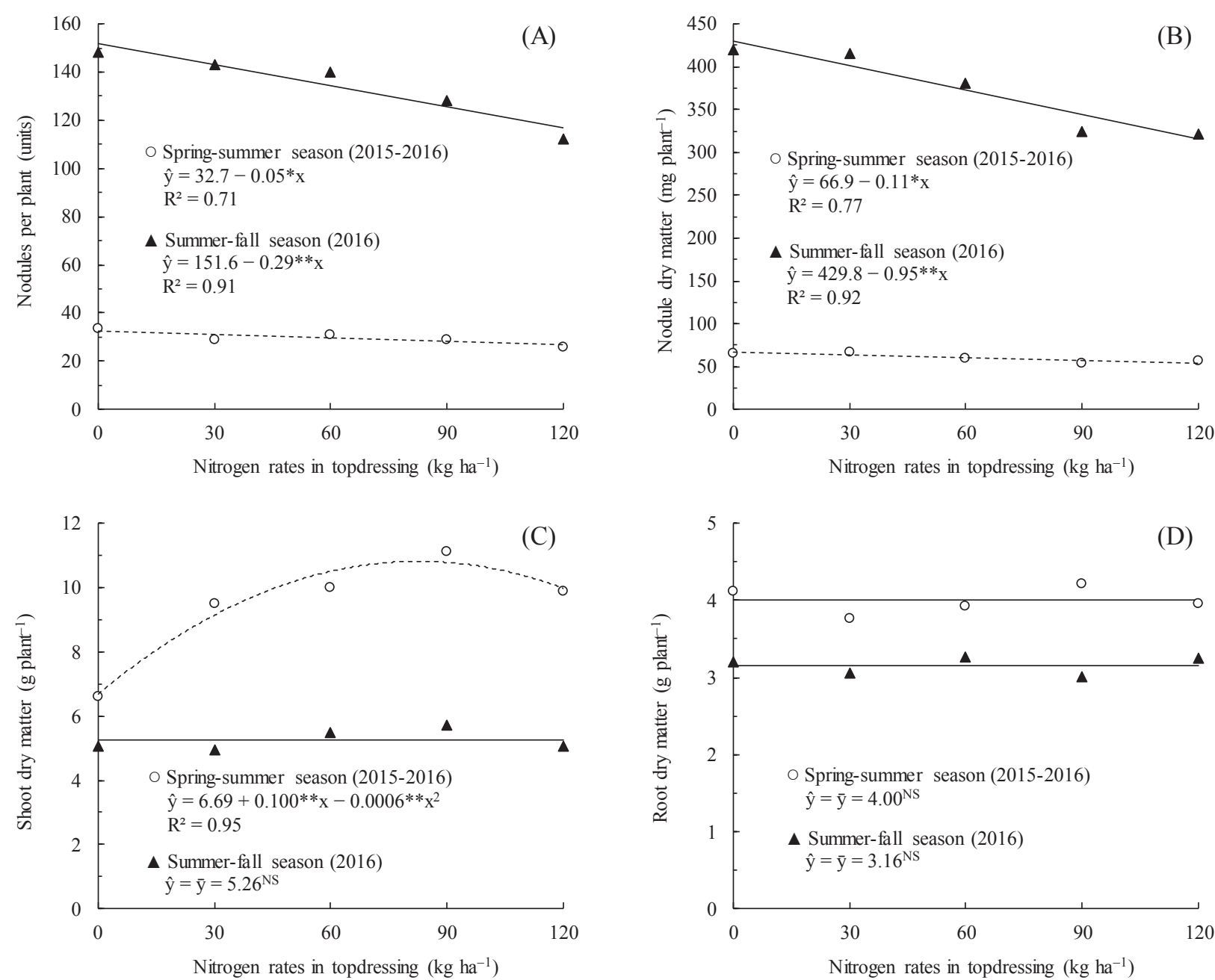
The $\mathrm{N}$ application rates in topdressing significantly affect $(P<0.05)$ the shoot dry matter in the spring-summer growth season (Figure 2C); however, the shoot dry matter in the summer-fall season and root dry matter in both growing seasons were not significantly affected $(P>0.05)$ by $\mathrm{N}$ fertilizer rates (Figure 2C and 2D). The highest accumulation of shoot dry matter in the springsummer season (10.9 $\mathrm{g} \mathrm{plant}^{-1}$ ) was obtained with application of $83 \mathrm{~kg} \mathrm{~N} \mathrm{ha}^{-1}$ in topdressing, whereas in the summer-winter season the accumulation of shoot dry matter remained constant in all the $\mathrm{N}$ rates (Figure 2C). These results show that the plant growth response to the application of $\mathrm{N}$ rates is dependent on the climatic conditions, and when the rainfall rate during the crop growing season is low the crop response to the application of $\mathrm{N}$ fertilizer is insignificant or null. Similarly, Peres et al. (2016) also found no positive response in the shoot dry matter accumulation of common beans with the application of $80 \mathrm{~kg} \mathrm{~N}^{-1}$ during the fall-winter season (i.e., dry season in the Brazilian tropical region). One of the main factors for the bean response to $\mathrm{N}$ fertilizer application in topdressing is soil moisture content, and when the crop is cultivated during the dry season, the lower water availability in the soil can result in low $\mathrm{N}$ response due to the increase of ammonia $\left(\mathrm{NH}_{3}\right)$ volatilization losses from $\mathrm{N}$ fertilizers. Indeed, Calvache et al. (1997) reported that the maximum response to $\mathrm{N}$ fertilization was only reached when the bean crop received adequate irrigation, and when there was some restriction of soil water the response to $\mathrm{N}$ fertilizer was reduced or null.

The $\mathrm{N}$ fertilizer rates in topdressing resulted in the greater RCI and $\mathrm{N}$ concentration of bean leaves in both growing seasons (Figure 3). The application of $120 \mathrm{~kg} \mathrm{~N} \mathrm{ha}^{-1}$ resulted in an increase of $22 \%$ and $15 \%$ in the chlorophyll levels compared to the not fertilized treatment with $\mathrm{N}$, respectively, for the spring-summer and summer-fall seasons (Figure 3A). Similarly, Silva et al. (2011) reported that the $\mathrm{N}$ fertilizer topdressing resulted in an increase in the chlorophyll level of two maize cultivars. Maia et al. (2013) applied $160 \mathrm{~kg} \mathrm{~N} \mathrm{ha}^{-1}$ in topdressing and, also verified chlorophyll levels $13 \%$ higher in common bean cv. IAC-Alvorada at 50 DAE. Souza and Soratto (2012) investigated the interaction between $\mathrm{N}$ and cropping systems and reported an increase in the chlorophyll levels in bean plants with $\mathrm{N}$ fertilizer application. These results were expected because $\mathrm{N}$ is a constituent element of many plant cell components, including the chlorophyll molecule. Therefore, increased $\mathrm{N}$ rates resulted in increased availability of this soil nutrient and, then, higher chlorophyll level (Figure 3A) and N concentration (Figure 3B) in the leaves.

In the spring-summer season, the highest leaf $\mathrm{N}$ concentration was obtained with the application of $75 \mathrm{~kg} \mathrm{~N} \mathrm{ha}^{-1}$ in topdressing, whereas the highest leaf $\mathrm{N}$ concentration in the summer-fall season was obtained with application of $86 \mathrm{~kg} \mathrm{~N} \mathrm{ha}^{-1}$ in topdressing (Figure 3B). As expected, $\mathrm{N}$ fertilizer application significantly increased $\mathrm{N}$ concentration the leaf tissue of bean plants. The significant increase in leaf $\mathrm{N}$ concentration with the application of $\mathrm{N}$ fertilizers has been commonly reported in Brazilian conditions (SANTOS; FAGERIA, 2007; SOUZA; SORATTO, 2012; MAIA et al., 2012, 2017; FIORENTIN et al., 2012; SORATTO et al., 2014). Nitrogen concentration in all treatments remained within the range of 30 to $50 \mathrm{~g} \mathrm{~kg}^{-1}$ considered appropriate for common bean nutrition by Ambrosano et al. (1997). 
Figure 3. Effect of nitrogen fertilizer rates in topdressing on relative chlorophyll index (A) and leaf nitrogen concentration (B) of common bean plants (Phaseolus vulgaris L., cv. Pérola) grown in a sandy soil from the Brazilian savanna region, during the two growing seasons ("spring-summer" and "summer-fall").
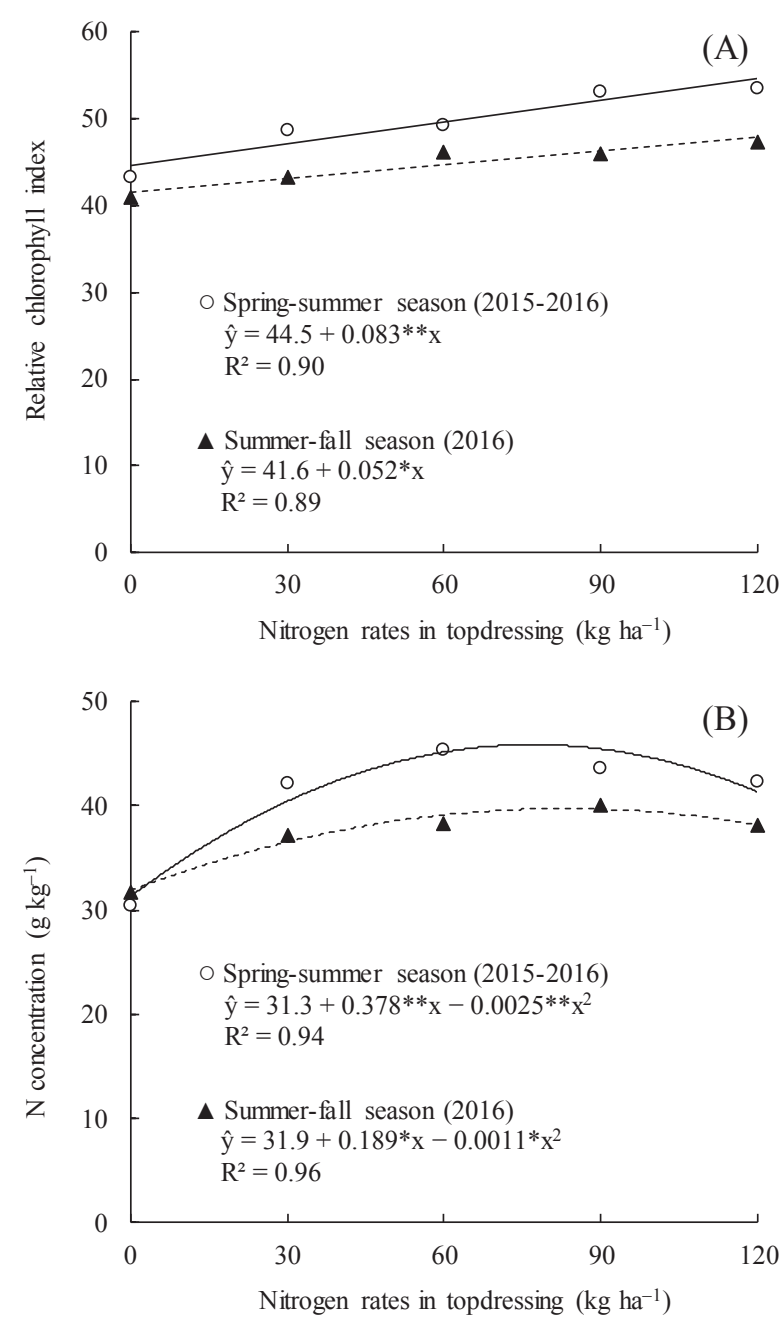

\section{Grain yield and production components}

Final plant stand was not significantly affected $(P>0.05)$ by inoculation or non-inoculation with $R$. tropici and $A$. brasilense and $\mathrm{N}$ application in topdressing, in both growth seasons (Table 3). The average final plant stand in spring-summer season was 213,053 plants $\mathrm{ha}^{-1}$, whereas in the summerfall season was 181,544 plants ha-1 (Table 2). The lowest population in the summer-fall season was due to the lower rainfall during this growing season, especially in the first 40 days after sowing (Figure 1). Therefore, lower rainfall in the summer-fall season resulted in failures in the plant establishment in the field. However, Souza et al. (2002) reported that the range from 100,000 to 400,000 plants ha $^{-1}$ results in equivalent grain yields due to the compensation capacity of the primary production components of beans, which provides similar productivity using different plant stands.

The inoculation with $R$. tropici and $A$. brasilense either alone or in combination significantly affect $(P<0.05)$ the pod number per plant; however, the grain number per pod and 100-grain weight were not significantly affected $(P>0.05)$ by inoculation or non-inoculation of the plants in both growth seasons (Table 3 ). In the spring-summer season, 
the inoculation of $R$. tropici combined with $A$. brasilense resulted in higher pod number per plant compared to the non-inoculated plants, whereas in the summer-fall season the inoculation with $R$. tropici alone resulted in higher number of pods per plant compared to non-inoculated plants (Table $3)$. In general, these results show that inoculation with $R$. tropici or A. brasilense either alone or in combination stimulated flower opening and pod formation in common bean plants. Similarly, Peres et al. (2016), which also observed a significant effect of the inoculation with $R$. tropici and A. brasilense alone or in combination on the number of pods. The increases in the numbers of flowers and pods may be a key factor for obtaining elevated levels of grain yield.

Table 3. Effect of (co)inoculation of Rhizobium tropici and/or Azospirillum brasilense on final plant stand, pod number per plant, grain number per pod, 100-grain weight, and grain yield of common bean crop (Phaseolus vulgaris L., cv. Pérola) grown in a sandy soil from the Brazilian savanna region, during the two growing seasons ("spring-summer" and "summer-fall").

\begin{tabular}{lccccc}
\hline \multirow{2}{*}{ Inoculation treatment } & Final plant stand & Pods per plant & Grains per pod & Mass of 100 grains & Grain yield \\
\cline { 2 - 6 } & (units) & (units) & (units) & $(\mathrm{g})$ & $\left(\mathrm{kg} \mathrm{ha}^{-1}\right)$ \\
\hline \multirow{5}{*}{ Control } & $218,324 \mathrm{a}$ & $11.25 \mathrm{~b}$ & $4.41 \mathrm{a}$ & $23.8 \mathrm{a}$ & $2,156 \mathrm{a}$ \\
Rhizobium tropici & $206,537 \mathrm{a}$ & $13.60 \mathrm{ab}$ & $4.75 \mathrm{a}$ & $25.6 \mathrm{a}$ & $2,424 \mathrm{a}$ \\
Azospirillum brasilense & $214,021 \mathrm{a}$ & $12.70 \mathrm{ab}$ & $4.54 \mathrm{a}$ & $24.7 \mathrm{a}$ & $2,356 \mathrm{a}$ \\
R. tropici + A. brasilense & $213,352 \mathrm{a}$ & $15.35 \mathrm{a}$ & $4.62 \mathrm{a}$ & $26.5 \mathrm{a}$ & $2,450 \mathrm{a}$ \\
\hline CV $(\%)$ & 7.93 & 9.46 & 8.82 & 9.74 & 13.52 \\
\hline & \multicolumn{5}{c}{ Summer-fall season $(2016)$} \\
Control & $184,970 \mathrm{a}$ & $10.11 \mathrm{~b}$ & $3.92 \mathrm{a}$ \\
Rhizobium tropici & $182,235 \mathrm{a}$ & $13.72 \mathrm{a}$ & $4.08 \mathrm{a}$ & $23.07 \mathrm{a}$ & $1,736 \mathrm{~b}$ \\
Azospirillum brasilense & $170,388 \mathrm{a}$ & $11.64 \mathrm{ab}$ & $4.01 \mathrm{a}$ & $23.82 \mathrm{a}$ & $2,082 \mathrm{a}$ \\
R. tropici + A. brasilense & $188,582 \mathrm{a}$ & $12.08 \mathrm{ab}$ & $4.12 \mathrm{a}$ & $25.69 \mathrm{a}$ & $2,831 \mathrm{~b}$ \\
CV $(\%)$ & 6.91 & 8.28 & 4.27 & 7.17 & 11.45 \\
\hline
\end{tabular}

Values represented by the different letters show significant differences (Tukey test, $\mathrm{p}<0.05$ ). CV: coefficient of variation.

The inoculation with $R$. tropici and $A$. brasilense either alone or in combination significantly affect $(P<0.05)$ the grain yield of beans only in the summer-fall season (Table 3 ). The grain yield was significantly greater when plants were inoculated with $R$. tropici alone and combined with $A$. brasilense (co-inoculation), and lower in the non-inoculated plants and with inoculation of $A$. brasilense alone (Table 3). The results for bean cropping in the summer-fall season report that inoculation with $R$. tropici increased bean yield by an average 346 $\mathrm{kgha}^{-1}$ (19.9\%), while co-inoculation of $R$. tropici combined with $A$. brasilense resulted in a mean yield increase of $462 \mathrm{kgha}^{-1}$ (26.6\%) in relation to the non-inoculated plants (Table 3). However, the grain yield was not significantly affected $(P>$ $0.05)$ by inoculation or non-inoculation with these rhizobacteria in the spring-summer season (Table 3).

These results suggest that the positive effects of inoculation with $R$. tropici and A. brasilense either alone or in combination on bean yield are dependent on environmental conditions, especially for the rainfall rate. The total rainfall during the spring-summer growth season was $535 \mathrm{~mm}$, while in the summer-fall growth season was only $242 \mathrm{~mm}$ 
(see Figure 1). Therefore, the positive response of inoculation with $R$. tropici alone or combined with $A$. brasilense on grain yield during the summerfall growing season may be due to increased plant tolerance to drought stress. Indeed, studies have shown that several PGPRs either alone or combined with rhizobia can mitigate the deleterious effects of drought stress in different plant species (DIMKPA et al., 2009; VURUKONDA et al., 2016). This induction of drought tolerance has been attributed especially to the ability of PGPRs in synthesize plant hormones such as auxin that enhanced root growth and formation of lateral roots they're by increasing the uptake of water and nutrients under water restriction conditions (CHIBEBA et al., 2015; VURUKONDA et al., 2016).

A common adaptation mechanism of plants exposed to drought stress includes changes in root morphology, a process in which plant hormones are known to play a key role (POTTERS et al., 2007), where, in low concentrations, they enhance cell elongation, resulting in enhanced root growth. Indeed, German et al. (2000) showed that inoculation of $A$. brasilense strains enhanced the tolerance of common beans to drought stress due to the increase of root length and volume compared with noninoculated plants. Promotion of root growth results in a larger root surface, and can, therefore, have positive effects on water acquisition and nutrient uptake (DIMKPA et al., 2009).

The inoculation with $A$. brasilense alone was not an efficient agronomic practice because it resulted in grain yield equivalent to the non-inoculated plants in both growing seasons (Table 3 ). Similar results were reported by Silva et al. (2017) in peanuts, who found that the inoculation with $A$. brasilense alone did not significantly affect nodulation and plant growth. These results show that leguminous plants are dependent on the inoculation of symbiotic bacteria (rhizobia), and inoculation of non-symbiotic bacteria (i.e., A. brasilense) alone has no beneficial effect on nodulation, plant growth, and crop yield. Therefore, the use of management practices that optimize the Rhizobium-bean symbiosis and biological $\mathrm{N}$ fixation of the crop is of extreme importance to obtain high grain yield indices.

The $\mathrm{N}$ application rates in topdressing significantly affect $(P<0.05)$ the pod number per plant, 100-grain weight, and grain yield; however, the grain number per pod was not significantly affected $(P>0.05)$ by $\mathrm{N}$ fertilizer rates in both growing seasons (Figure 4 ). In the spring-summer season, the pod number per plant increased from 10.0 units in the not fertilized treatment with $\mathrm{N}$ to a maximum of 15.1 units with application of $75 \mathrm{~kg}$ $\mathrm{N} \mathrm{ha}^{-1}$ in topdressing, whereas the highest number of pods per plant (13.0 units) in the summer-fall season was obtained with application of $81 \mathrm{~kg} \mathrm{~N}$ ha $^{-1}$ in topdressing (Figure 4A).

The highest 100-grain weight (26.6 g) in the spring-summer season was obtained with the application of $85 \mathrm{~kg} \mathrm{~N} \mathrm{ha}^{-1}$ in topdressing, whereas the 100-grain weight in the summer-fall season increased progressively with increasing $\mathrm{N}$ fertilizer rate in topdressing (Figure 4C). A large amount of $\mathrm{N}$ is extracted and exported by the common bean crop (SORATTO et al., 2014) since its grain is constituted by $20-25 \%$ protein (i.e., an $\mathrm{N}$ macromolecule). Therefore, the increase of grain weight with the application of $\mathrm{N}$ rates was expected. Santos and Fageria (2007) also reported a significant increase in the bean grain weight with $\mathrm{N}$ application.

The bean yield in the spring-summer season increased from $1,676 \mathrm{~kg} \mathrm{ha}^{-1}$ in the not fertilized treatment with $\mathrm{N}$ to a maximum of $2,696 \mathrm{~kg} \mathrm{ha}^{-1}$ with the application of $83 \mathrm{~kg} \mathrm{~N} \mathrm{ha}^{-1}$ in topdressing, indicating a maximum increase in grain yield of $61 \%$. In the summer-fall season, the grain yield increased from $1,286 \mathrm{~kg} \mathrm{ha}^{-1}$ in the not fertilized treatment with $\mathrm{N}$ to a maximum of $2,300 \mathrm{~kg} \mathrm{ha}^{-1}$ with the application of $90 \mathrm{~kg} \mathrm{~N} \mathrm{ha}^{-1}$ in topdressing, indicating a mean increase in grain yield of $79 \%$ (Figure 4C). 
Figure 4. Effect of nitrogen fertilizer rates in topdressing on pod number per plant (A), grain number per pod (B), 100-grain weight (C), and grain yield (D) of common beans (Phaseolus vulgaris L., cv. Pérola) grown in a sandy soil from the Brazilian savanna region, during the two growing seasons ("spring-summer" and "summer-fall").
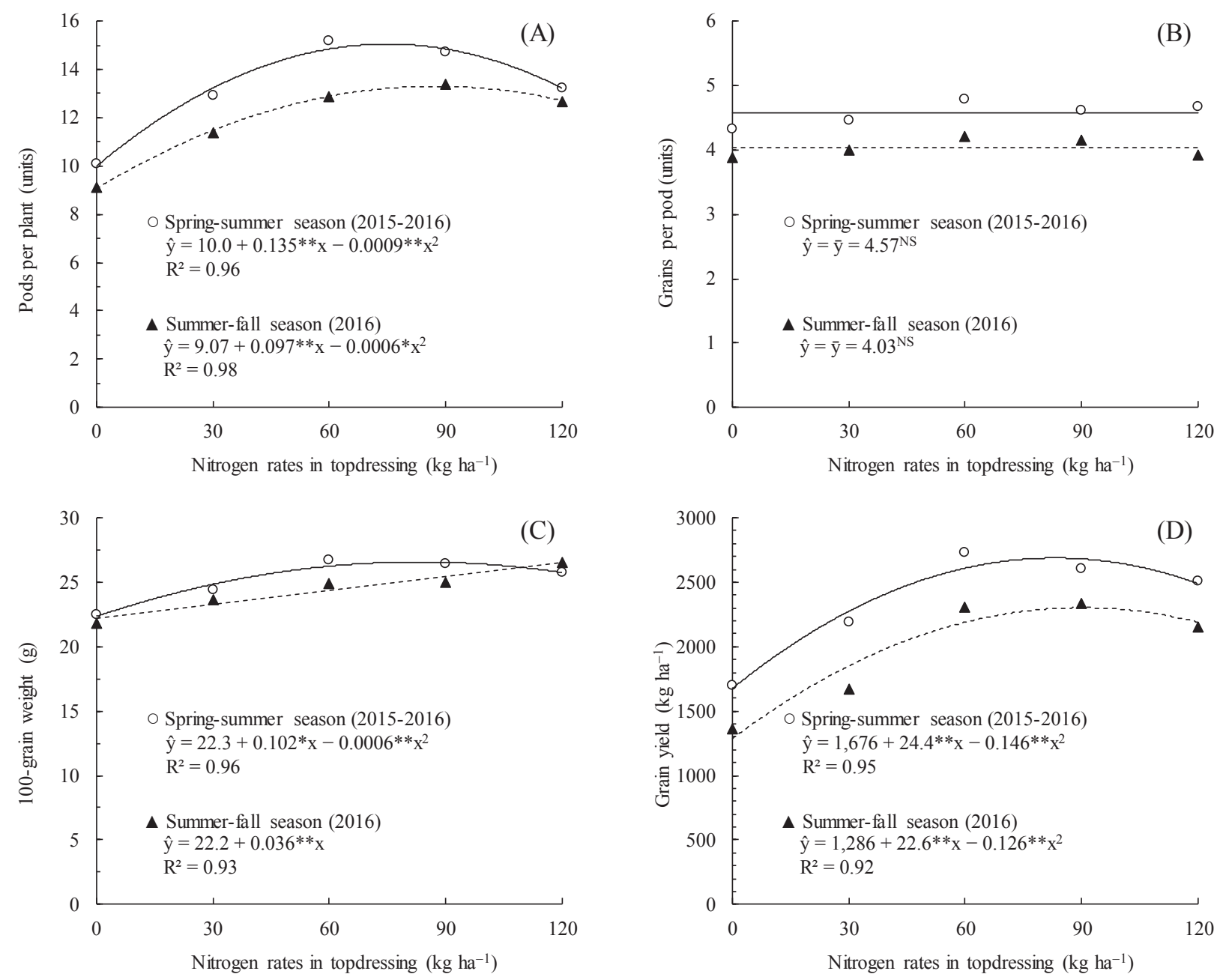

The positive response of the beans to the application of $\mathrm{N}$ fertilizers has been commonly reported in the tropical conditions of Brazil (SOUZA; SORATTO, 2012; MAIA et al., 2012, 2017; FIORENTIN et al., 2012; PELEGRIN et al., 2009). Indeed, Maia et al. (2012) found that the application of 80 and $160 \mathrm{~kg} \mathrm{~N} \mathrm{ha}^{-1}$ in topdressing resulted in an increase in the bean grain yield during the rainy growing season of $657 \mathrm{~kg} \mathrm{ha}^{-1}(35 \%)$ and $1,127 \mathrm{~kg} \mathrm{ha}^{-1}(60 \%)$, respectively, compared to the not fertilized treatment with N. Similarly, Maia et al. (2017), evaluating $\mathrm{N}$ application rates in the yield of the common beans verified that the application

of $150 \mathrm{~kg} \mathrm{~N} \mathrm{ha}^{-1}$ in topdressing resulted in a mean increase of $816 \mathrm{~kg} \mathrm{ha}^{-1}(25 \%)$ in comparison to the not fertilized treatment with N. Souza and Soratto (2012) reported that the highest yield $\left(2,225 \mathrm{~kg} \mathrm{ha}^{-1}\right)$ of the beans grown on Palisade grass residues was obtained with the application of $110 \mathrm{~kg} \mathrm{~N} \mathrm{ha}^{-1}$ in topdressing. Pelegrin et al. (2009) observed that the maximum grain yield of beans is obtained with the application of $98 \mathrm{~kg} \mathrm{~N} \mathrm{ha}^{-1}$ in topdressing. However, Fiorentin et al. (2012) recommended the application of $160 \mathrm{~kg} \mathrm{~N} \mathrm{ha}^{-1}$ in topdressing for the common bean crop sown in succession to maize, justifying that this rate results in greater economic profitability of 
the crop. These results report the importance of the adequate supply of $\mathrm{N}$ fertilizer to obtain high grain yields of the bean. Nitrogen is the nutrient taken up in highest amounts by common bean since around 35 to $50 \mathrm{~kg}$ of $\mathrm{N}$ is utilized for each ton of bean grains produced (SORATTO et al., 2013). The variability in grain yield responses to $\mathrm{N}$ rates in the different regions of Brazil has been verified especially as a function of soil fertility levels and management techniques used in production systems.

In general, the results presented here show that the rhizobia inoculation combined with the application of chemical $\mathrm{N}$ fertilizer can contribute to greater profitability for the common bean cropping in the sandy soils of the Brazilian Cerrado. However, considering that the chemical fertilizer $\mathrm{N}$-use is one of the main factors that increase the costs of bean production, the use of biological inoculants should be an option to be adopted by farmers to increase the profitability of bean cropping.

\section{Conclusions}

The inoculation with Rhizobium tropici alone or combined with Azospirillum brasilense enhanced root nodulation and grain yield of the common beans when the crop was grown during the dry season in the Brazilian savanna region. This suggests that the positive response of inoculation with rhizobia and azospirilla on the grain yield is dependent of the environmental conditions during the growing season, especially the lower rainfall rate by stimulating root nodulation.

The inoculation with $A$. brasilense alone was not an efficient agronomic practice because to be used in common beans cropping under Brazilian conditions, resulting in grain yield equivalent to the non-inoculated plants in the two growing seasons.

The increase of nitrogen application rates inhibits the formation and growth of root nodules of the common beans.
The optimal nitrogen application rate in topdressing for common beans grown on sandy soil from the Brazilian savanna region may range between 80 and $90 \mathrm{~kg} \mathrm{~N} \mathrm{ha}^{-1}$.

\section{Acknowledgments}

To CNPq (National Council for Scientific and Technological Development) and UEMS (State University of Mato Grosso do Sul) for the scientific initiation scholarship granted to the second author.

\section{References}

AMBROSANO, E. J.; TANAKA, R. T.; MASCARENHAS, A. A.; RAIJ, B. V.; QUAGGIO, J. A.; CANTARELLA, H. Leguminosas e oleaginosas. In: RAIJ, B. V.; CANTARELA, H.; QUAGGIO, J. A.; FURLANI, A. M. C. (Ed.). Recomendações de adubação e calagem para o Estado de São Paulo. Campinas: Instituto Agronômico de Campinas, 1997. p. 189-204. (Boletim técnico, 100).

BULEGON, L. G.; GUIMARÃES, V. F.; KLEIN, J.; BATISTTUS, A. G.; INAGAKI, A. M.; OFFMANN, L. C.; SOUZA, A. K. P. Enzymatic activity, gas exchange and production of soybean co-inoculated with Bradyrhizobium japonicum and Azospirillum brasilense. Australian Journal of Crop Science, Lismore, v. 11, n. 7, p. 888-896, 2017.

CALVACHE, A. M.; REICHARDT, K.; MALAVOLTA, E.; BACCHI, O. O. S. Efeito da deficiência hídrica e da adubação nitrogenada na produtividade e na eficiência do uso de água em uma cultura do feijão. Scientia Agricola, Piracicaba, v. 54, n. 3, p. 232-240, 1997.

CASSÁN, F.; PERRIG, D.; SGROY, V.; MASCIARELLI, O.; PENNA, C.; LUNA, V. Azospirillum brasilense Az39 and Bradyrhizobium japonicum E109, inoculated singly or in combination, promote seed germination and early seedling growth in corn (Zea mays L.) and soybean (Glycine max L.). European Journal of Soil Biology, Montrouge, v. 45, n. 1, p. 28-35, 2009.

CHIBEBA, A. M.; GUIMARÃES, M. F.; BRITO, O. R.; NOGUEIRA, M. A.; ARAUJO, R. S.; HUNGRIA, M. Co-inoculation of soybean with Bradyrhizobium and Azospirillum promotes early nodulation. American Journal of Plant Science, Irvine, v. 6, n. 10, p. 16411649, 2015. 
COMPANHIA NACIONAL DE ABASTECIMENTO - CONAB. Levantamento da safra 2016/17: grãos. Brasília: Conab, 2017. Disponível em: <http://www. conab.gov.br>. Acesso em: 28 jan. 2018.

DIMKPA, C.; WEINAND, T.; ASCH, F. Plantrhizobacteria interactions alleviate abiotic stress conditions. Plant, Cell and Environment, Logan, v. 32, n. 12, p. 1682-1694, 2009.

ECKARDT, N. A. The role of flavonoids in root nodule development and auxin transport in Medicago truncatula. The Plant Cell, Norwich, v. 18, n. 7, p. 1539-1540, 2006.

FERREIRA, A. N.; ARF, O.; CARVALHO, M. A. C.; ARAÚJO, R. S.; SÁ, M. E.; BUZETTI, S. Estirpes de Rhizobium tropici na inoculação do feijoeiro. Scientia Agricola, Piracicaba, v. 57, n. 3, p. 507-512, 2000.

FIORENTIN, C. F.; LEMOS, L. B.; JARDIM, C. A.; FORNASIERI-FILHO, D. Adubação nitrogenada de cobertura no feijoeiro de inverno-primavera em três sistemas de cultivo. Semina: Ciências Agrárias, Londrina, v. 33, n. 1, p. 2825-2836, 2012.

FUKAMI, J.; CEREZINI, P.; HUNGRIA, M. Azospirillum: benefits that go far beyond biological nitrogen fixation. $A M B$ Express, London, v. 8, n. 73, p. 1-12, 2018.

GERMAN, M. A.; BURDMAN, S.; OKON, Y.; KIGEL, J. Effects of Azospirillum brasilense on root morphology of common bean (Phaseolus vulgaris L.) under different water regimes. Biology and Fertility of Soils, Firenze, v. 32, n. 3, p. 259-264, 2000.

HUBBELL, D. H.; KIDDER, G. Biological nitrogen fixation. Florida: University of Florida IFAS Extension Publication SL16, 2009. 4 p.

HUNGRIA, M.; CAMPO, R. J.; SOUZA, E. M.; PEDROSA, F. O. Inoculation with selected strains of Azospirillum brasilense and A. lipoferum improves yields of maize and wheat in Brazil. Plant and Soil, Amsterdam, v. 331, n. 1-2, p. 413-425, 2010.

HUNGRIA, M.; NOGUEIRA, M. A.; ARAUJO, R. S. Co-inoculation of soybeans and common beans with rhizobia and azospirilla: strategies to improve sustainability. Biology and Fertility of Soils, Firenze, v. 49, n. 7, p. 791-801, 2013.

Soybean seed co-inoculation with Bradyrhizobium spp. and Azospirillum brasilense: a new biotechnological tool to improve yield and sustainability. American Journal of Plant Sciences, Irvine, v. 6, n. 6, p. 811-817, 2015.
MAIA, S. C. M.; SORATTO, R. P.; BIAZOTTO, F. O.; ALMEIDA, A. Q. Estimativa da necessidade de nitrogênio em cobertura no feijoeiro IAC Alvorada com clorofilômetro portátil. Semina: Ciências Agrárias, Londrina, v. 34, n. 5, p. 2229-2238, 2013.

MAIA, S. C. M.; SORATTO, R. P.; LIEBE, S. M.; ALMEIDA, A. Q. Criteria for topdressing nitrogen application to common bean using chlorophyll meter. Pesquisa Agropecuária Brasileira, Goiânia, v. 52, n. 7, p. 512-520, 2017.

MAIA, S. C. M.; SORATTO, R. P.; NASTARO, B.; FREITAS, L. B. The nitrogen sufficiency index underlying estimates of nitrogen fertilization requirements of common bean. Revista Brasileira de Ciência do Solo, Viçosa, v. 36, n. 1, p. 183-191, 2012.

MALAVOLTA, E. A.; VITTI, G. C.; OLIVEIRA, A. S. Avaliação do estado nutricional das plantas: princípios e aplicações. 2. ed. Piracicaba: Potafos, 1997. 319 p.

MARKS, B. B.; MEGÍAS, M.; NOGUEIRA, M. A.; HUNGRIA, M. Biotechnological potential of rhizobial metabolites to enhance the performance of Bradyrhizobium japonicum and Azospirillum brasilense inoculants with the soybean and maize crops. Applied Microbiology and Biotechnology, Washington, v. 3, n. 21, p. 1-10, 2013.

PELEGRIN, R.; MERCANTE, F. M.; OTSUBO, I. M. N.; OTSUBO, A. A. Resposta da cultura do feijoeiro à adubação nitrogenada e à inoculação com rizóbio. Revista Brasileira de Ciência do Solo, Viçosa, v. 33, n. 1, p. 219-226, 2009.

PERES, A. R.; RODRIGUES, R. A. F.; ARF, O.; PORTUGAL, J. R.; CORSINI, D. C. D. C. Co-inoculation of Rhizobium tropici and Azospirillum brasilense in common beans grown under two irrigation depths. Revista Ceres, Viçosa, v. 63, n. 2, p. 198-207, 2016.

PERRIG, D.; BOIERO, L.; MASCIARELLI, O.; PENNA, C.; CASSÁN, F.; LUNA, V. Plant growth promoting compounds produced by two agronomically important strains of Azospirillum brasilense, and their implications for inoculant formulation. Applied Microbiology and Biotechnology, Washington, v. 75, n. 5, p. 1143-1150, 2007.

POTTERS, G.; PASTERNAK, T. P.; GUISEZ, Y.; PALME, K. J.; JANSEN, M. A. K. Stress-induced morphogenic responses: growing out of trouble? Trends in Plant Science, Amsterdam, v. 12, n. 3, p. 98-105, 2007.

RAMALHO, M. A. P.; ABREU, A. F. B. Cultivares. In: VIEIRA, C.; PAULA JUNIOR, T. J. P.; BORÉM, A. (Ed.). Feijão. Viçosa, MG: Universidade Federal de Viçosa, 2006. p. 415-436. 
SAITO, A.; TANABATA, S.; TANABATA, T.; TAJIMA, S.; UENO, M.; ISHIKAWA, S.; OHYAMA, T. Effect of nitrate on nodule and root growth of soybean (Glycine $\max$ (L.) Merr.). International Journal of Molecular Sciences, Basel, v. 15, n. 3, p. 4464-4480, 2014.

SANTOS, A. B.; FAGERIA, N. K. Manejo do nitrogênio para eficiência de uso por cultivares de feijoeiro em várzea tropical. Pesquisa Agropecuária Brasileira, Brasília, v. 42, n. 9, p. 1237-1248, 2007.

SANTOS, K. C.; UCHÔA, S. C. P.; MELO, V. F.; ALVES, J. A.; ROCHA, P. R. R.; XIMENES, C. K. S. Inoculação com Bradyrhizobium e adubação nitrogenada em feijão-caupi cultivado em diferentes solos. Revista Agro@mbiente, Boa Vista, v. 8, n. 3, p. 306-317, 2014.

SILVA, E. R. S.; BUSH, A.; ZUFFO, A. M.; STEINER, F. Coinoculação de Bradyrhizobium japonicum e Azospirillum brasilense em sementes de amendoim de diferentes tamanhos. Revista de Agricultura Neotropical, Cassilândia, v. 4, n. 5, p. 93-102, 2017.

SILVA, M. A. G.; MUNIZ, A. S.; MANNIGEL, A. R.; PORTO, S. M. A.; MARCHETTI, M. E.; NOLLA, A.; GRANNEMANN, I. Monitoring and evaluation of need for nitrogen fertilizer topdressing for maize leaf chlorophyll readings and the relationship with grain yield. Brazilian Archives of Biology and Technology, Curitiba, v. 54, n. 4, p. 665-674, 2011.

SORATTO, R. P.; FERNANDES, A. M.; SANTOS, L. A.; JOB, A. L. G. Nutrient extraction and exportation by common bean cultivars under different fertilization levels: I - macronutrients. Revista Brasileira de Ciência do Solo, Viçosa, v. 37, n. 4, p. 1027-1042, 2013.

SORATTO, R. P.; PEREZ, A. A. G.; FERNANDES, A. $M$. Age of no-till system and nitrogen management on common bean nutrition and yield. Agronomy Journal, Madison, v. 106, n. 3, p. 809-820, 2014.

SOUZA, E. F. C.; SORATTO, R. P. Adubação nitrogenada no feijoeiro após milho safrinha consorciado com Urochloa brizantha e Urochloa ruziziensis. Semina: Ciências Agrárias, Londrina, v. 33, n. 1, p. 2669-2680, 2012.

SOUZA, A. B.; ANDRADE, M. J. B.; MUNIZ, J. A.; REIS, R. P. Populações de plantas e níveis de adubação e calagem para o feijoeiro (Phaseolus vulgaris L.) em um solo de baixa fertilidade. Ciência e Agrotecnologia, Lavras, v. 26, n. 1, p. 87-98, 2002.

VURUKONDA, S. S. K. P.; VARDHARAJULA, S.; SHRIVASTAVA, M.; SKZ, A. Enhancement of drought stress tolerance in crops by plant growth promoting rhizobacteria. Microbiological Research, Gurgaon, v. 184, n. 3, p. 13-24, 2016.

WASSON, A. P.; PELlERONE, F. I.; MATHESIUS, U. Silencing the flavonoid pathway in Medicago truncatula inhibits root nodule formation and prevents auxin transport regulation by rhizobia. The Plant Cell, Norwich, v. 18, n. 7, p. 1617-1629, 2006. 
